\title{
The violence dynamics in public security: military interventions and police-related deaths in Brazil
}

OÑATI SOCIO-LEGAL SERIES VOLUME 11, ISSUE 3 (2021), 787-808: INVESTIGATIONS - INVESTIGACIONES

- IKERLANAK

DOI LINK: HTTPS://DOI.ORG/10.35295/OSLS.IISL/0000-0000-0000-1181

RECEIVED 30 JULy 2020, ACCEPTED 24 NOVEMBER 2020

\author{
MARCIAL A.G. SUAREZ* (iD) \\ LUÍS ANTÔNIO FRANCISCO DE SOUZA* ID \\ CARLOS HENRIQUE AGUIAR SERRA* ID
}

\section{Abstract}

This paper discusses the deadly use of violence as a public security agenda, focusing on police lethality and military interventions. Through a literature review to understanding concepts - such as "war," for example - used in public security policy agendas, the study seeks to frame the notion of political violence, mainly referring to the policies designed to combat violence in Brazil. The objective is to problematize the public security policy based on the idea of confrontation, which adopts the logic of war and the notion of "enemy". The paper is divided into three parts. The first is a conceptual approach to violence and war, and the second is the analysis of the dynamic of deadly use of force. Finally, the third part is a contextual analysis of violence in Rio de Janeiro, its characteristics, and central actors, using official statistics on violence in the region.

\section{Key words}

Public security; Brazil; police lethality; military interventions

\section{Resumen}

Este artículo se ocupa del uso letal de la violencia como parte de los programas de seguridad pública. Nos centramos en la letalidad policial y las intervenciones

\footnotetext{
* Marcial A. Garcia Suarez, Associated Professor of Political Sciences at Universidade Federal Fluminense, Departamento de Ciência Política e Programa de Pós-Graduação em Ciência Política. Campus do Gragoatá - Rua Professor Marcos Waldemar de Freitas Reis, Bloco O. Rio de Janeiro - RJ, Brasil, CEP 24210-201. Email: marcialgsuarez@gmail.com

* Luís Antônio Francisco de Souza, Professor of Sociology at Universidade Estadual Paulista Julio de Mesquisa Filho, Unesp. Av. Hygino Muzzi Filho, 737 - Marília, São Paulo, Brazil - CEP: 17.525-900. Email: lafraso@hotmail.com

* Carlos Henrique Aguiar Serra, Associated Professor of Political Sciences and PhD in History at Universidade Federal Fluminense. Rua Clarice Índio do Brasil, 30/601 - Botafogo - Rio de Janeiro, Brazil CEP: 22230-090. Email: chaserra@id.uff.br
} 
militares. A través de un repaso de la literatura para entender algunos conceptos -por ejemplo, "guerra"- utilizados en los programas de políticas de seguridad pública, pretendemos enmarcar la noción de violencia política, refiriéndonos principalmente a las políticas diseñadas para combatir la violencia en Brasil. El objetivo es problematizar la política de seguridad pública basada en la idea de confrontación, la cual adopta la lógica de la guerra y la noción de un "enemigo". El artículo se divide en tres partes: la primera es un acercamiento conceptual a la violencia y la guerra, y la segunda es el análisis de la dinámica del uso letal de la fuerza. Finalmente, la tercera parte es un análisis contextual de la violencia en Río de Janeiro, sus características y sus actores principales, utilizando estadísticas oficiales de la violencia en la región.

\section{Palabras clave}

Seguridad pública; Brasil; letalidad policial; intervenciones militares 


\section{Table of contents}

1. Violence and war: conflictive representations ............................................................ 790

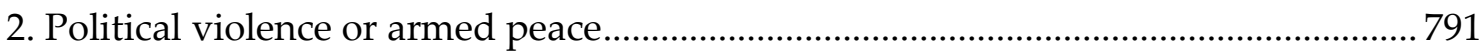

3. Police lethality and military interventions as public security agenda.........................794

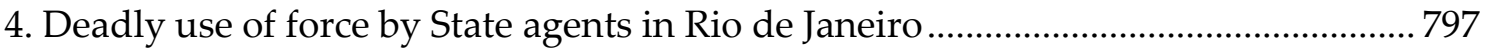

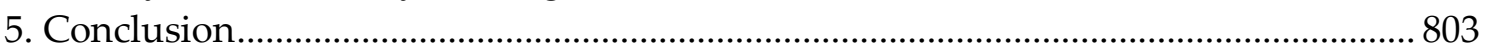

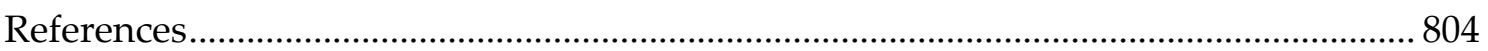




\section{Violence and war: conflictive representations}

When it comes to crime in Latin America, and particularly in Rio de Janeiro, the concepts of "violence" and "war" are close, even blending. In analytical terms, however, there are differences between these concepts, as well as several forms of violence - such as political violence - that must be recognized.

According to Clausewitz (1996, p. 5), "war is an act of violence intended to compel our opponent to fulfill our will." The author makes use of the concept of "violence" by explicitly defining it as the capacity of one political entity to attack another. However, he offers a second critical comment, when stating that "war is an act of violence pushed to its utmost bounds" (Clausewitz, 1996, p. 10). ${ }^{1}$

It is important to observe the scale of violence when seeking an introductory definition of "war". This concern implies discussing how much aggression is in a hostile act. The definition of quantity may be summarized in the term "science of violence" as portrayed by S. Wolin (1960) when discussing Machiavelli:

$\ldots$ and the basic reason is not alone that Machiavelli regarded the science of violence as the means for reducing the amount of suffering in the political condition, but that he was aware of the dangers of entrusting its use to the morally obtuse. (Wolin 1960, p. 241)

Another issue to observe in the debate on the scale of violence within the definition of "war" is the "legal entity" representing the political actors who may formally provoke war.

For Vivienne Jabri (2007), the issue of representation significantly contributes to understanding the real dimension of war and violence, when there is the intention to eliminate an unwanted attitude or event. For the author, "however, war constitutively involves direct violence, though the use of the term in recent times has expanded to cover policies aimed at the combat of undesirable social problems, such as the so-called 'war on drugs' or the 'war on obesity'” (Jabri 2007, p. 12).

Following Jabri's (2007) thread of thought, it is possible to adopt different perspectives regarding the use of the term "war". First of all, the term is not precise in its normative dimension, and the concept entails a debate concerning the political objective - which is different from the objective as portrayed by Clausewitz, considering that, in this case, "war" may be used according to a scale of violence. Therefore, the term "war" gains legitimacy as a concept that may refer to some social issues.

During the 1980s, 1990s, and 2000s, Latina America provided a political context for the emergence of criminal groups (Call 2003, Kurtenbach 2013), characterized by factors such as several economic crises and the end of intra-state conflicts. This period produced a political legacy of resentment and an abundance of firearms in the hands of civilians. The social constraints that many countries in Latin America have faced do not support the explanations based on institutional control, which suggests that social control would prevent criminal activities. According to Neumayer (2003), the absence of a stable family

\footnotetext{
${ }^{1}$ This reflection was brought up first by Michel Foucault (1999) and then by Agamben (2004a). According to this critical discussion, war is not only seen in its extension to democracy (and, therefore, normalized). War can also be an analysis of modernity.
} 
structure, employment, and economic security, could explain, to a certain extent, the trigger for criminal behavior.

The absence of inter-state conflicts in the Latin America and Caribbean region was recognized at the $2^{\text {nd }}$ Summit of the Community of Latin American and Caribbean States (CELAC) in 2014 in Havana, where the region was declared a zone of peace. The question that naturally arises is: what kind of peace are we talking about? Peace as the absence of conflict or peace as the absence of war? The answer seems evident, the peace then declared in 2014 by 33 countries, reflected a scenario of an absence of inter-state conflicts, but in no way addressed the recent past events in the region, which indicated that violence was still a challenge. ${ }^{2}$

On the other hand, when preliminarily analyzing the data on homicide in Latin America, "peace" does not represent a political/social environment of low violence for the population. The number of gun deaths in the Americas indicates that the notion of "peace" as "absence of inter-state war" is not suitable in the region since the average homicide rate is the highest in the world. In Brazil, according to data from the 2017 United Nations Office on Drugs and Crime, the homicide rate per 100,000 inhabitants was 30.5; in El Salvador, 61.8; Colombia, 24.9; Honduras, 41.7; Guatemala, 26.1; Mexico, 24.8 , just to name the most violent countries.

When comparing the homicide rate in South America with the Global average, the numbers indicate a disturbing singularity. While the average homicide rate per 100,000 inhabitants is 6.1 in the rest of the world, in South America, this rate rises to 24.1, approximately $400 \%$ higher.

The scenario of violence in South America and, more so considering all of Latin America, leads to a reflection on the reality of the security policies adopted in the region. It is important to analyze their effectiveness regarding the improvement of the relationships between the State - as the legitimate holder of the means of violence - and society as a whole, subject of the state's protection.

\section{Political violence or armed peace}

According to Holland (2013), the literature in political science and sociology uses the term "political violence" to designate a variety of concepts, such as casual police brutality (Pereira and Ungar 2006), politicians with authoritarian tendencies (Chevigny 2003), non-democratic political preferences, and citizens' extra-judicial proceedings (Godoy 2006, Goldstein et al. 2007). Nieburg (1968) and Grundy and Weinstein (1974) consider political violence and social violence as two unique phenomena that complement each other. Moser (2004) explores the phenomenon of violence in different categories (political, institutional, economic, and social). Political violence is in constant motion and overlaps in different characteristics so that violence can be political and institutional or economic and social at the same time, as the author proposed in the chart:

\footnotetext{
2 The current advance of the hybrid war policy promoted by the USA in the region, the war returned to the political agenda and the daily life of South American countries, following the model of the war on drugs.
} 
CHART 1

\begin{tabular}{|c|c|c|}
\hline \multicolumn{3}{|c|}{ Roadmap of categories, types, and manifestations of violence in urban areas } \\
\hline Category of violence & $\begin{array}{c}\text { Types of violence by } \\
\text { perpetrators and/or victims }\end{array}$ & Manifestations \\
\hline Political & - State and non-state violence & $\begin{array}{l}\text { - Guerrilla conflict } \\
\text { - Paramilitary conflict } \\
\text { - Political assassinations } \\
\text { - Armed conflict between } \\
\text { political parties }\end{array}$ \\
\hline Institutional & $\begin{array}{l}\text {-Violence of state and other } \\
\text { "informal” institutions. } \\
\text { • Including the private sector }\end{array}$ & $\begin{array}{l}\text { - Extra-judicial killings by } \\
\text { police } \\
\text { • physical or psychological } \\
\text { abuse by health and education } \\
\text { workers } \\
\text { - State or community vigilante- } \\
\text { directed social cleansing of } \\
\text { gangs and street children } \\
\text { - Lynching of suspected } \\
\text { criminals by community } \\
\text { members }\end{array}$ \\
\hline Economic & $\begin{array}{l}\text {-Organized crime } \\
\text { • Business interests } \\
\text { • Delinquents } \\
\text { - Robbers }\end{array}$ & $\begin{array}{l}\text { - Intimidation and violence as a } \\
\text { mean of resolving economic } \\
\text { disputes } \\
\text { - Street theft, robbery, and crime } \\
\text { - Kidnapping } \\
\text { - Armed robbery } \\
\text { - Drug-trafficking } \\
\text { - Car theft and other contraband } \\
\text { activities } \\
\text { - Small-arms dealing } \\
\text { - Assaults including killing and } \\
\text { rape in the course of economic } \\
\text { crimes } \\
\text { - Trafficking in prostitutes } \\
\text { - Conflict over scarce resources }\end{array}$ \\
\hline Economic/social & $\begin{array}{l}\text { - Gangs } \\
\text { - Street children (boys and } \\
\text { girls) } \\
\text { - Ethnic violence } \\
\end{array}$ & $\begin{array}{l}\text { - Territorial or identity-based } \\
\text { "turf" violence; robbery, theft } \\
\text { • Petty theft } \\
\text { - Communal riots }\end{array}$ \\
\hline Social & $\begin{array}{l}\text { - Intimate partner violence } \\
\text { inside the home } \\
\text { - Sexual violence (including } \\
\text { rape) in the public arena } \\
\text { - Child abuse: boys and girls } \\
\text { - Inter-generational conflict } \\
\text { between parent and children } \\
\text { - Gratuitous/routine daily } \\
\text { violence }\end{array}$ & $\begin{array}{l}\text { Physical or psychological male- } \\
\text { female abuse } \\
\text { - Physical and sexual abuse, } \\
\text { particularly prevalent in the case } \\
\text { of stepfathers but also uncles } \\
\text { - physical and psychological } \\
\text { abuse } \\
\text { - Incivility in areas such as } \\
\text { traffic, road rage, bar fights, and } \\
\text { street confrontations } \\
\text { - Arguments that get out of } \\
\text { control }\end{array}$ \\
\hline
\end{tabular}

Chart 1. Categories of violence.

(Source: Moser 2004, p. 5.)

According to Galtung $(1985,1991)$, we need a notion of violence that covers more than situations of evident brutality, including more implicit forms, such as exploitation, 
exclusion, inequality, and injustice. The issue of negative and positive peace implies an understanding of the conditions of violence. Negative peace emerges as the imposition, by the state's intervention, of the absence of direct violence. The author emphasizes, however, that this condition is not permanent since it does not alter the determinants of conflict. As for positive peace, it supports a broad process of political action that changes the structure of the state of affairs that originates from violent action. Therefore, positive peace allows political stability, built based on a new configuration.

According to Fox and Hoelscher (2012), institutionalized democracies have experienced lower levels of social violence. However, although all Latin American countries are democratic or have "hybrid" regimes, the homicide rates in all of them remain high, with an average of 23.1 murders per 100,000 people in the region. The correlation between the high number of democratic institutions and low levels of violence is not observed in the Latin American context. Kleinfeld and Barham (2018) question how so many democratic or quasi-democratic countries, with relatively stable capacity, are unable to prevent widespread violence. The authors argue that groups of the elite use violence to maintain power and extreme privileges within an almost democratic context, creating a limited democracy that restricts the political choices of the middle class and the severely socioeconomic marginalized population.

A theoretical approach to violence may explain the logic that leads a person to act with violence. Rivera (2016), and Thyne and Shroeder (2012) suggest four theoretical concepts around this issue: motivation, control, opportunity, and constraints. Motivation refers to the conditions that can lead to violence, for example, social inequality (Hagan and Peterson 1995). According to Rivera (2016), the explanation of acts of violence based on control has attracted significant attention among scholars and policymakers in LA, mainly due to the recognition that the fragility of states is related to the wave of crime and violence (O'Donnell 1993, Munck 2003). Opportunity refers to rational choice, which is persuaded by the idea that there is a low prospect of punishment, so this type of analysis is less concerned with the institution and more interested in the social interactions from which criminal behavior emerges.

The assumptions discussed in this paper are aligned with the reflections developed by Agamben (2004a). Here, we assume that the rule of law produces permanent exceptions. In other words, the rule of law and the state of exception are not antagonistic. There is a dialectical and complementary relationship that indicates, in a very concrete way, the complex relationship between "legalities" and "illegalities." Therefore, it is fair to say that the rule of law produces, on a large scale, its illegalities.

The notion of the 'state of exception' by Giorgio Agamben (2004a) shows that militarization corresponds to the normalization of militarism. Its consequences are the limitations on rights and legitimation of state violence, notably, the police violence.

The tendency is to understand this image of Brazil from the perspective of an exception that becomes a rule (Agamben 2004a). The state of exception is both a configuration of legal institutions and a general government tactic adopted by the emerging social multiplicities. It reinforces the authoritarian-repressive law enforcement apparatus and brings ambiguity to the limits between legality and illegality. The state of exception is then the political space in which violence is justified even when it directly violates the 
legal norm because it allows the activation of the mechanisms of war (Agamben 2004a, 2004b). ${ }^{3}$

The military prominence in dealing with the force and risks impacting people's lives and deaths is a desire within the use of militarized management. This type of management creates new porous and imprecise borders between life and death. Thus, there is no contradiction between the politicization of death and the bio-political power strategy (Foucault 1999). The militarization of the state apparatus and the nationalization of paramilitary groups demonstrate that the power of death and destruction is central to bio-political strategies that produce social inequalities and asymmetries in the distribution of power in the country. Death or the possibility of death is part of the militarized bio-political strategy. The forms of military intervention are the sovereign exception, insofar as the police undertake the power of death - predicted in war situations - and the militarism rationalizes this power as a permanent struggle against an imaginary enemy. Thus, killing is a way to control who "deserves" to live at the cost of the massacre of who "deserves" dying. ${ }^{4}$

Governing the population and life management makes the high cost of death acceptable as a safety and risk management strategy. In this sense, it is essential to remember that state violence and the subtler forms of economic risk management are not exclusive. In the wake of the dismantling of the welfare state, western societies have invested in the model of social control through incarceration, the ghettoization of entire social groups, widespread high-tech surveillance, and the systematic violation of citizenship rights (Wacquant 1999, Bauman 1999, 2003, Garland 2008, Beck 2010). Therefore, these characteristics do not contradict the militarized model of security.

\section{Police lethality and military interventions as public security agenda}

The emergence of a conservative wave started in 2015, where groups managed to gain political prominence and power based on narratives emphasizing the confrontation of violence through public security policies supported by a notion of combat and extermination. Omar G. Encarnación (2016) defined this phenomenon as "the Trumpification of the Latin American right".

The conservative wave phenomenon can be demonstrated with the election of Juan Orlando Hernandez in Honduras in 2014, Mauricio Macri in Argentina in 2015, Jimmy Morales in Guatemala in 2015, Michel Temer in Brazil in 2016 (after the impeachment of Dilma Rousseff), Sebastián Piñera in Chile in 2015, and Jair Bolsonaro in Brazil in 2018. These leaders managed to obtain electoral victories amidst a political context of a

\footnotetext{
${ }^{3}$ In his work State of Exception, Agamben mentions two important authors - even though completely different: Carl Schmitt and Walter Benjamin. Agamben elaborates his conception of "state of exception" based on the "dialogues" between these two authors. He moves away from Schmitt and gets closer to Benjamin, especially when embracing the view that the law also produces violence. It is important to observe that Agamben refers to the "sovereign decision" which, for Schmitt, means a hostile confrontation space between friend and enemy, and the consequence is that only one can survive because the existence of the enemy is the reason for political unity (Schmitt 1992, p. 52).

${ }^{4}$ The high rates of police killings and the constant campaign to increase the police death power, as well as the exemption from guilt of policemen tried before the jury demonstrate the degree of legitimacy of the state of permanent war in which the death of the "criminal" is always justified. According to Agamben (2004a), the enemy - the criminal -, is killable, but unsacrificeable.
} 
broader crisis in the area of public security and escalating crime in Latin America, which remains the most violent region in the world (according to the United Nations Development Programme - UNDP - (2018), the homicide rate in the region in 2018 was 23.1 per 100,000 inhabitants).

In this political scenario, public security proved to be an issue fueling political campaigns. Conservative parties managed to gain voters' attention with a proposal of quick results through simple solutions. The right-wing parties, therefore, expanded their political narrative beyond the traditional focus on the economy, engaging the population with an appealing narrative covering moral issues (Holland 2013).

In 2017, according to the Rio de Janeiro Public Security Institute (Instituto de Segurança Pública do Rio de Janeiro 2018), 4,432 people were murdered in the metropolitan area. A survey by the Datafolha Institute and the Public Security Forum found that $76 \%$ of the population of Rio de Janeiro support federal intervention in the state's public security. Also, $92 \%$ are afraid of being killed in a robbery, $87 \%$ are afraid of being murdered, and $75 \%$ (almost 4 million people) declared to have heard shootings in the neighborhood at least once. However high homicides rates are not exclusively of Rio de Janeiro, some of the most violent cities of Brazil are in the northeast and north region, as Fortaleza in Ceará and Rio Branco in the state of Acre:

\section{GRAPH 1}

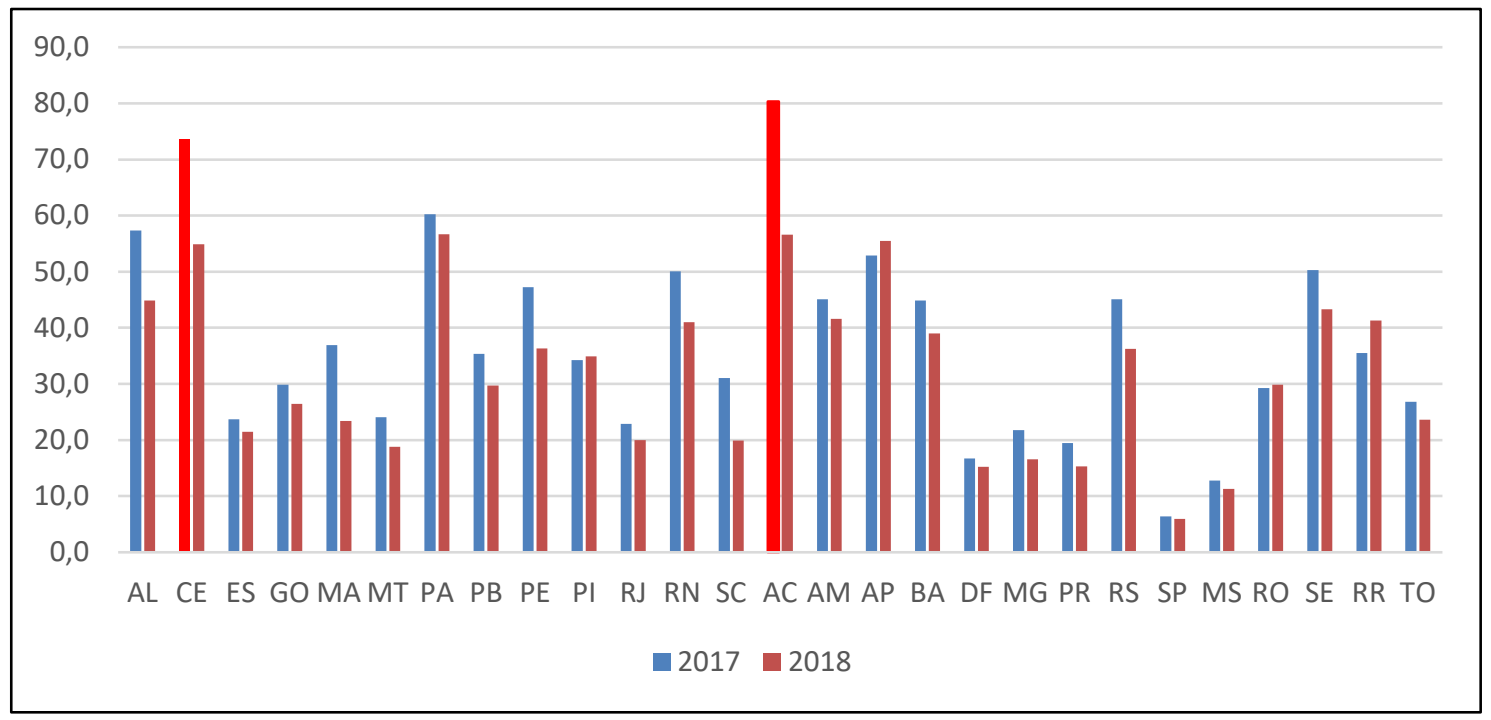

Graph 1. Homicides rate in the state's capitals of Brazil in 2017-2018 per 100,000 individuals. (Source: Fórum Brasileiro de Segurança Pública 2018.)

In February 2018, the Brazilian federal government declared intervention in the public security of the state of Rio de Janeiro, based on the Presidential Decree 9288. The measure was taken amidst a massive media campaign to influence public opinion. The decree allowed the state to hand over the control of all security infrastructure and agents to the armed forces, and more than 3,000 soldiers were deployed to Rio de Janeiro.

As a result of hardening public security agenda and the popular belief in a positive correlation of police lethality and social security lead to an increase of police-related deaths that could see through an analysis of data from Fórum de Segurança Publica (Public Security Forum). When comparing police-related deaths between 2013-2018 it is possible to have a glimpse of how the lethality of police forces in Brazil was being 
implemented. It is important to take the graph in two moments, from 2013 up to 2015 the police lethality increased about 67\%, however taking the period of 2015-2018 the increase was about to $86 \%$, the second-period match with the increase of the political crisis that led to the affirmation of conservative groups which won 2016 and 2018 elections with a political narrative of a more deadly crime control policies.

\section{GRAPH 2}

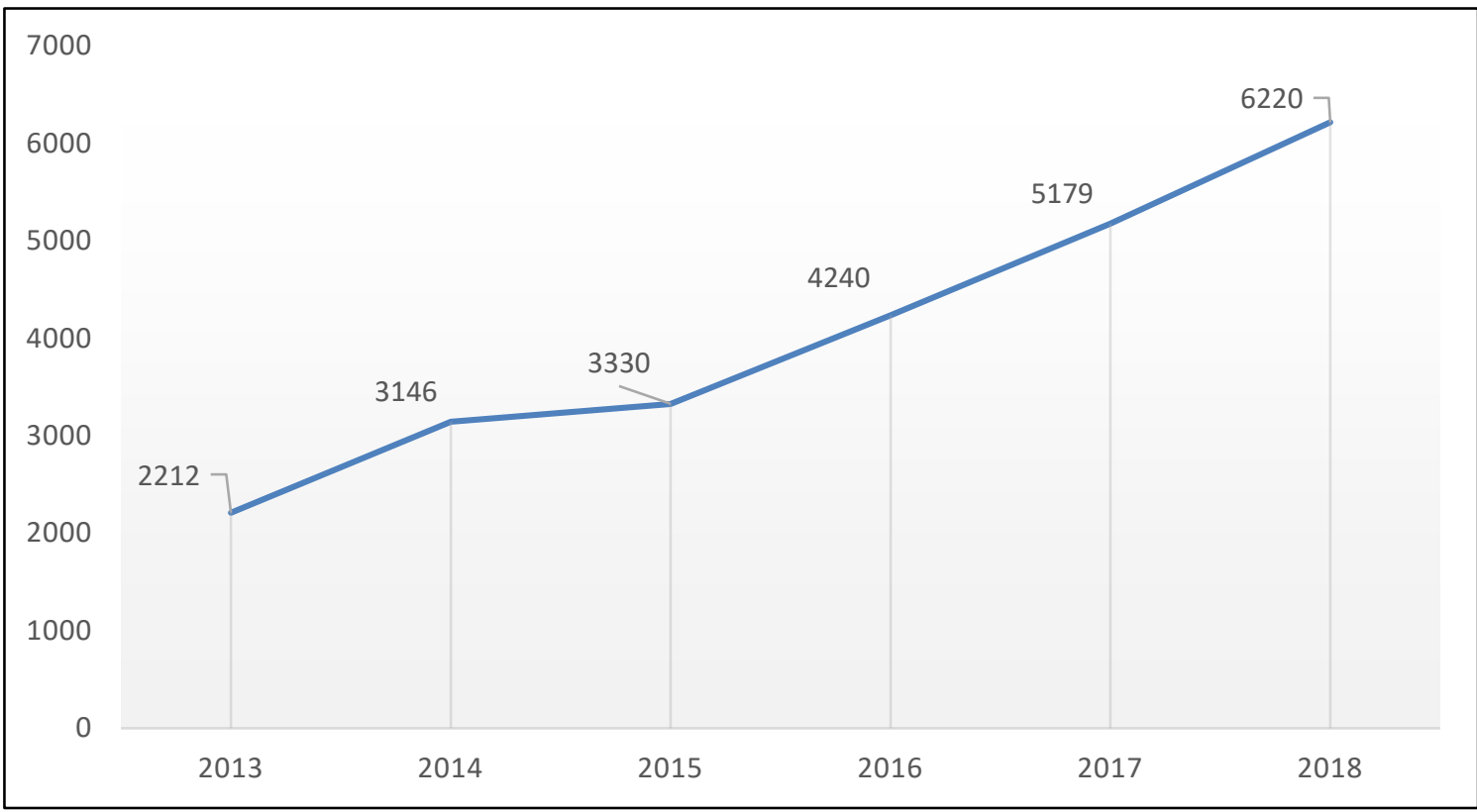

Graph 2. Police-related deaths in Brazil.

(Source: Fórum Brasileiro de Segurança Pública 2019. p 66.)

The context of (in)security all over the country was an opportunity to explore more lethality in security public policies. The 2018 presidential and gubernatorial elections expressed this narrative and gained public support in several important Brazilian states such as Rio de Janeiro, São Paulo, Minas Gerais, Rio Grande do Sul, and Santa Catarina, resulting in the election of President Jair Bolsonaro. It is important to stress that the phenomenon of electoral processes supporting the public security agenda contemplating confrontational and violent policies is not exclusively observed in Brazil.

Rodgers and Baird (2016) propose that the national and regional dimensions of public choices indicate that crime is defined in the context of action and the perception of actors subjected to violence. Violence and criminality are related and should be analyzed based on the new actors involved and the political contexts. During the cold war between the capitalist and the socialist worlds, the latter was faced as the "enemy par excellence" in a broad structure of securitization (Buzzan et al. 1998) of national and international political relations. After the cold war, from the 1990s onwards, the so-called violent nonstate actors (VNSAs) took the role of "enemy". In this sense, the political and economic agenda reoriented the political actors. For Koonings and Kurijt (1999) and Pearce (1998), an inflection of ideological conflicts over the ontology of political regimes for a more immediate version of violence (crime and delinquency), emerged in the field of intra and inter-state conflicts. 


\section{Deadly use of force by State agents in Rio de Janeiro}

The first part of this paper offered a theoretical framework about violence, discussing the concept of 'war' and introducing the use of the term to reflect the issue of political violence. Also, the study pointed out the necessary understanding of how political discourses approach and instrumentalize the issue of violence to explore the limits of the legal system according to the political objectives of a given agenda.

The question addressed in this section is, what does it mean that Rio de Janeiro is a state under a deadly public security policy? According to reports of the Public Security Forum (2014-2018), violent non-state actors that are widely dispersed throughout the national territory are organized in criminal groups that are directly or indirectly linked, and that keep local or national relationships among themselves. To understand the linkages of organized crime in Brazil, we can see the map, wherein the light blue Brazilian states we'll find a unique group leading the criminal activity, and in the Brazilian states with dark blue we'll see more than one organized crime group what leads to a potential conflict scenario:

\section{MAP 1}

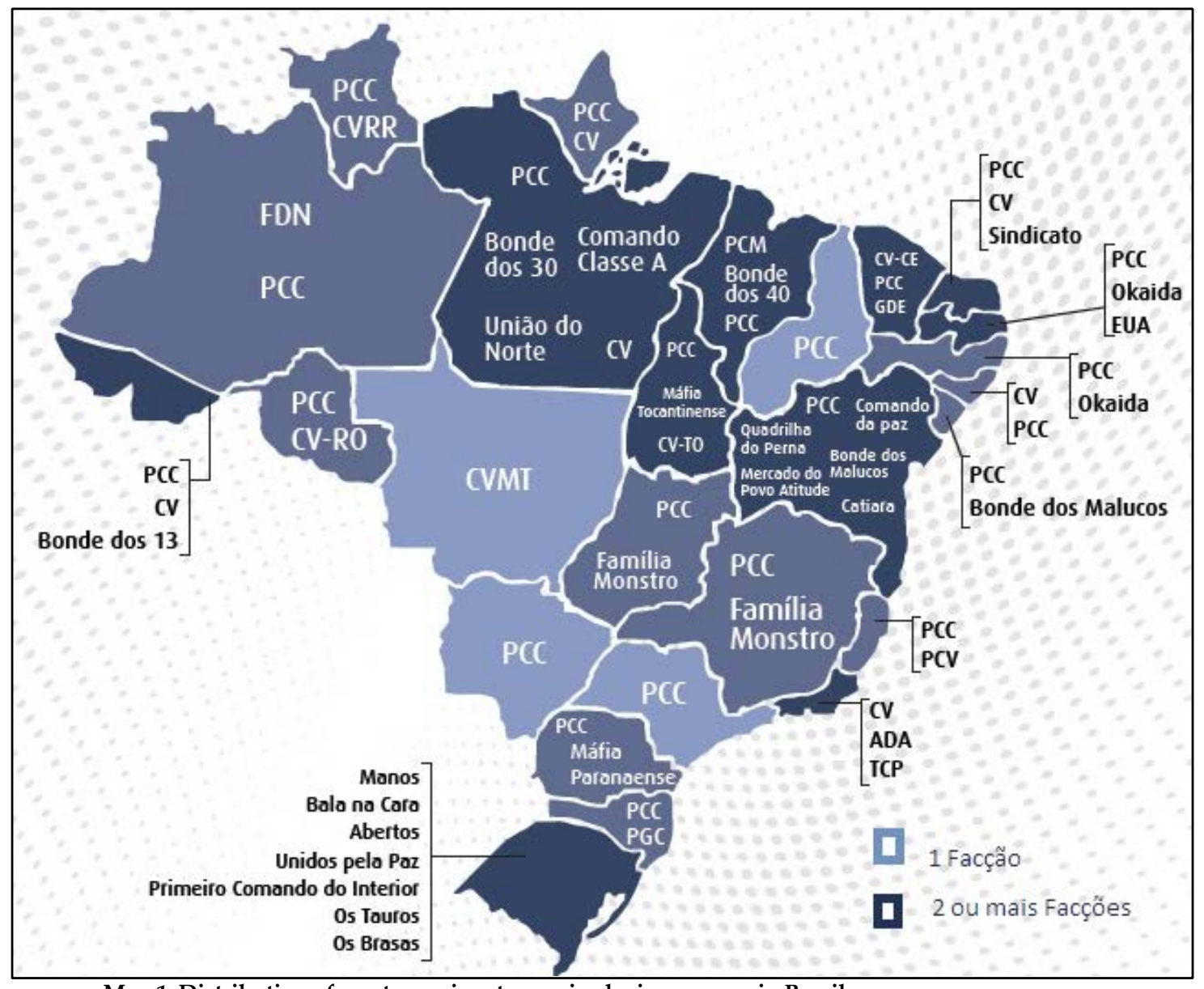

Map 1. Distribution of most prominent organized crime groups in Brazil.

(Source: Fórum Brasileiro de Segurança Pública 2018.)

The empirical basis analyzed is the federal intervention in the state of Rio de Janeiro public security in 2018, with the military occupation of territories and proactive policing. The intervention was a laboratory for repressive and violent security measures and a test to legitimize the military management of public security, adopting the permanent 
construction of an enemy, within the logic of war and armed confrontation. ${ }^{5}$ The 2018 intervention is not the first federal intervention in Brazilian states. ${ }^{6}$

The past intervention experiences did not achieve the intended goals. This study focuses on the events in Rio de Janeiro since they are exemplary of the relationship between militarization and the increase in state violence. Much of the justification for federal military interventions revolve around the so-called "war on organized crime and drug trafficking". Over the past decade, the state has relied on the armed forces at least twelve times.

The city of Rio de Janeiro was occupied by men in camouflage uniforms, snipers, armored cars, armored helicopters, as well as various strategies associated with stages of a "war". In recent years, the armed forces have been engaged in police activities such as searching people, vehicles, boats, and detaining people at borders. Brazil has invested civil security institutions and more in specific intervention instruments, whose definition, identity, legal status, and forms of control are ambivalent, as is the case with the National Security Force. ${ }^{7}$

Armed Forces officers are present in many areas of the government, occupying positions in the intelligence agencies and security institutions. The state police forces work in agencies of the public administration, both at the state and local levels. The military never left the space of politics and still occupy important positions in the public bureaucracy, at the three levels of government (Nóbrega 2010, Paoliello and Miklos 2017). Internationally, Brazilian military forces worked with the UN, playing a leading role in Haiti's social and political stabilization. Also, the security of major international events in Brazil was planned and had the proactive presence of the Armed Forces. One example was the 2013 FIFA Confederations Cup, which counted on a military operation formed by 23 thousand soldiers, and an investment of U\$ 140 million (Godoy 2013). Another example was the security during the Pope's visit in 2013. At least 10,000 military personnel and 6,500 state police officers were involved in Pope Francis' visit at the World Youth Day in Rio de Janeiro (Amâncio 2018).

Actions to guarantee law and order are provided for in article 142 of the Federal Constitution, regulated by complementary law 97/1999 and presidential decree $3897 / 2001$. According to the legislation, such actions refer to the use of the Armed Forces in situations where there is an understanding that local police forces are no longer able to deal with a crisis. This is a "legal monstrosity" that legitimizes the state of exception. Nevertheless, the indicators of criminal violence continued their upward trend (Redação 2018).

The military intervention of February 2018 in the state of Rio de Janeiro represented an authoritarian mystification, and the activities with 360 military operations and 170,000

\footnotetext{
${ }^{5}$ The military intervention was a paradigmatic experience. During this period, the population in poorer areas of Rio de Janeiro lived as if in concentration camps, in a true state of siege. The policies' most obvious result of the intervention was the increase in police killings, without any forceful criticism against such atrocities (Betim 2018).

${ }^{6}$ The novelty about the 2018 federal intervention is the fact that it was authorized by the Brazilian Congress and based on the constitutional provisions.

${ }^{7}$ The existence of the National Security Force is still the subject of controversy. Many specialists consider the creation and activities of the force to be unconstitutional (Velasquez 2015).
} 
armed soldiers could not produce any lasting effect except for the permanent need for further intervention. ${ }^{8}$ Handing over the states' public security to the Army generals strengthens militarism and contributes to a permanent state of exception, with the normalization of such interventions. Military actions are overt, but the results are meager. In general, these operations are not more than strategies to manage poverty in one of the places with the most inequality - particularly the city of Rio de Janeiro - in the country, as a way of forcing the exercise of power and the illegitimate political succession.

After more than a year since the end of the interference, the presence of military personnel in the public security of Rio de Janeiro is higher than before the crisis that led the state to request their support. The terrible results of the period for the population, however, did not prevent voters from electing the military's candidate running for president.

The data regarding the operations were astonishing. From February to December 2018, the number of shootings grew 56\% (5,238 shootings between February and December 2017, against 8,193 shootings between February and December 2018). Killing by law enforcement agents increased by $36.3 \%$, reaching a total of 1,287 deaths. Intentional homicides, which were more than 4,422 in 2017 , decreased by only $6.7 \%$, to 4,127 in the same period in 2018. There were 53 mass murders, with 213 deaths. During the period, 103 officers of public security died (see http://observatoriodaintervencao.com.br/).

The intervention, therefore, stems from a tendency to militarize public security. This militarization violates the citizens' rights, putting the population in favelas and peripheral areas in a state of siege, submitted to illegal systematical searches, home invasion, arbitrary arrests, and unauthorized mass identification. ${ }^{9}$ It represents a humiliation for residents in underprivileged areas, who see themselves - their "bodies" - confined within borders controlled by military forces (Caldeira 2001). In this scenario, the "use of bodies" (Agamben 2017) reflects the emblematic "cog" in the production process. It is a notion of "using" that surpasses the "subject/object and active/passive scissions" (Agamben 2017).

\footnotetext{
${ }^{8}$ The budget for the military intervention in Rio de Janeiro was of U\$ 240 million. The Intervention Office spent only $6 \%$ of the total (U\$ 17 million), of which U\$ 12 million was allocated to the Armed Forces. The funds directed to the state public security agencies was limited to approximately U\$ 1,8 million (See http://observatoriodaintervencao.com.br/).

9 "Although the intervention of the federal government in Rio's public security is an unprecedented event since the 1988 Constitution, this is not the first time that the Brazilian Armed Forces carry out such operation in the state. The decree to guarantee law and order (GLO) have been used by all Brazil's former presidents since Fernando Collor's mandate (1990-1992) in order to allow the Army to patrol the Brazilian states' territory during major events, such as the UN Earth Summit in Rio de Janeiro in 1992 and, more recently, the 2014 FIFA World Cup and the Rio 2016 Summer Olympics. The decree was also used in cases the Army had to assist states' security forces in containing the violence of criminal groups. Violence indicators - such as the homicide rate - however, have always returned to the same levels after the intervention (in 2017, for instance, [the state of Rio de Janeiro counted] 40 murders per 100 thousand inhabitants. An example of the waste of public resources occurred between April 2014 and June 2015, when the favelas complex in the region of Maré, north of [the city of] Rio [de Janeiro], was occupied by Army military personnel, at an estimated cost of U\$120 million, without reducing the violence in the region. In 2017, President Temer spent U\$ 2 million on an operation that invaded Rocinha and resulted in the seizure of a small number of guns." (Vilela 2018; our translation).
} 
Military interventions in public security are made legally based on worrisome infraconstitutional legislative adjustments. It is important to be aware, particularly, of the provisions that attempt to remove from the regular legal proceedings the trials regarding crimes committed by the military when performing police roles. ${ }^{10}$

The case of Rio de Janeiro is compelling because of three central players, the criminal groups Comando Vermelho (CV), Amigos dos Amigos (ADA), and Terceiro Comando Puro (TCP). A fourth player must be mentioned, the militia groups. All these actors are representatives of the violent non-state actors operating with significant influence in the territory. The clash among these criminal groups, drug trafficking operators, and militias - all of them with ties to public agencies, and political representation in the cities and the state legislative branches - is an element that contributes to the complexity of the scenario of confrontation proposed by the state agents.

The militias in Rio de Janeiro originated with death squads established in the 1960s (Burgos 2002, Alves 2003, Zaluar and Conceição 2007, Misse 2011). The most famous at that time was the Esquadrão da Morte do Detetive Le Coq (Detective Le Coq's Death Squad). In this period, the Scuderie Le Coq was created, composed of the self-styled Homens de Ouro (Golden Men) of the Rio de Janeiro's police. This group was responsible for coining and disseminate the motto "a good criminal is a dead criminal", which has been used not only by the populace nationwide but also as a motto in political campaigns.

The group called Polícia Mineira (police from Minas Gerais) was a variation of the death squads created in the 1960s/1970s. They emerged in the 1980s when police officers and former police officers started to privately offer security to small businesses and locations further away from the city center of Rio de Janeiro. The term "polícia mineira" was inspired by groups of police officers from the state of Minas Gerais well known for violent practices. After the 1990s, the dynamics of these groups changed, improving the economic/violent relationship between militias and the population. According to Burgos (2002) and Zaluar and Conceição (2007), resident associations were introduced as a new arrangement for the "business". From then on, the militia started to offer protection not only to small commerce but also to the population in general. The territories started to be divided into sectors, under the "jurisdiction" of these groups.

The Liga da Justiça (Justice League), perhaps one of the most successful organizations of this nature, emerges in the West Zone of Rio de Janeiro and expands, establishing branches and divisions. The region of Rio das Pedras, in the West Zone of Rio de Janeiro, is known as the epicenter from which the militia-based form of violence control expanded throughout the city of Rio de Janeiro. The structure and ranks of militia's groups of Rio de Janeiro was recently analyzed for Manso: “In Lobo's understanding, the partnership with the local police battalion and political tolerance for the work of the

\footnotetext{
10 "It was with great perplexity that the legal community received Law 13491/2017, recently sanctioned. The law expands the competence of the Federal Military Justice and, as we will see, also of the State Military Justice" (Lopes 2017, our translation). These illegal adjustments to the law, characteristic of a state of exception, are the foundations of the changes proposed by the new minister of justice. If any of these changes occur, Brazil will literally legalize police killings (See Benites 2019).
} 
militiamen are structural and a condition for the functioning of the militia services in Rio de Janeiro" (Manso 2020, p. 11).

In an interview for the newspaper $O$ Globo, Attorney Luiz Antônio Ayres exposes the complexity of the issue of public security and militia organizations. Ayres mentioned the data from the Public Prosecutor's Office in Rio de Janeiro, informing that around 26 out of $160(16.5 \%)$ neighborhoods in the city are under the control of militia groups, or approximately 2.2 million people.

According to Ayres, the dispersion of the militia groups occurs in a planned manner, aiming to take control of the North Zone of the city. The Attorney said that, at that moment, there was a dispute among drug dealers and militia groups to control the region of Cidade de Deus, which has witnessed a series of clashes and deaths resulting from the dispute among the criminal groups and police operations in 2018.

The issues of crime, public security, and policies related to the control and reduction of violence, find in Rio de Janeiro a circle of error and repetition, with little room for implementing new agendas to safeguard the population. Over the past 30 years, public security policy has been built on the logic of combating, apparently disregarding selfevident facts: a) the criminal offenses related to organized crime, and b) violence is not exclusive to a segregated (socially economically, and racially) portion of the population.

When considering the central players in the equation of violence in Rio de Janeiro, we are dealing with a complex combination of economic, social, political, and, more recently, religious interactions. Therefore, the equation and its complexity do not find an answer in a binary policy, which takes up the also binary motto of Scuderie Le Coq - a good criminal is a dead criminal.

According to a study carried out by the Research Center of the Public Prosecutor's office in Rio de Janeiro (CENPE/MPRJ), it is not possible to establish a direct correlation between the application of public security policy based on combating violence with strategies that increase the number of killings by law enforcement agents, and an outcome of decreasing homicide rate, although police killing reached 1,256 by July 2019 against 1,075 in the previous period. This statement is supported by a detailed analysis of data revealing a drop in the homicide rate, and the number of killings by law enforcement actors on the integrated areas of public security in Rio de Janeiro.

According to the report of a total of 39 Integrated Public Security Areas (AISP), four of them account for $42 \%$ of the drop in the homicide rate across the state of Rio de Janeiro. The AISP of Queimados (24) indicated a 2.5\% drop in the homicide rate and an increase of 9.4\%. Nova Iguaçu (20), São Gonçalo (7), Rio das Ostras (32), and Angra dos Reis (33) show a non-linear correlation between killings by law enforcement agents and the drop in the homicide rate. Of these five areas, only São Gonçalo, with an increase of $13.2 \%$ and Queimados with 9.4\%, registered an increase in deaths due to the intervention of State agents. The locations of Nova Iguaçu registered a drop of $20.7 \%$, Rio das Ostras $10.5 \%$, and Angra dos Reis with 31.\%. On the other hand, the lethality rate in Santa Cruz in the West Zone of Rio de Janeiro dropped by $90 \%$ while the rate of intentional homicides dropped $1.2 \%$.

These preliminary data deserve further analysis. However, they suggest that the "success" of the confrontation policy based on the extermination of the "enemy" (with 
the motto "a good criminal is a dead criminal") does not find support in the data recorded by the Public Security Institute or by the analysis carried out by the Public Prosecutor's Office of the State of Rio de Janeiro (MPJR, 2019). There is no general causal relationship to support the argument that the decrease in the homicide rate in Rio de Janeiro is linked to a type of public security policy structured exclusively on confrontation. Rio de Janeiro shows the tightening of security policies through police lethality. In 2019 the police of Rio de Janeiro killed 1,814, taking into account the last ten years the lethality of the police of Rio de Janeiro is increasing, however since 2017 and brings up an impressive average of police deaths per suspect that reaches 50.28.

\section{GRAPH 3}

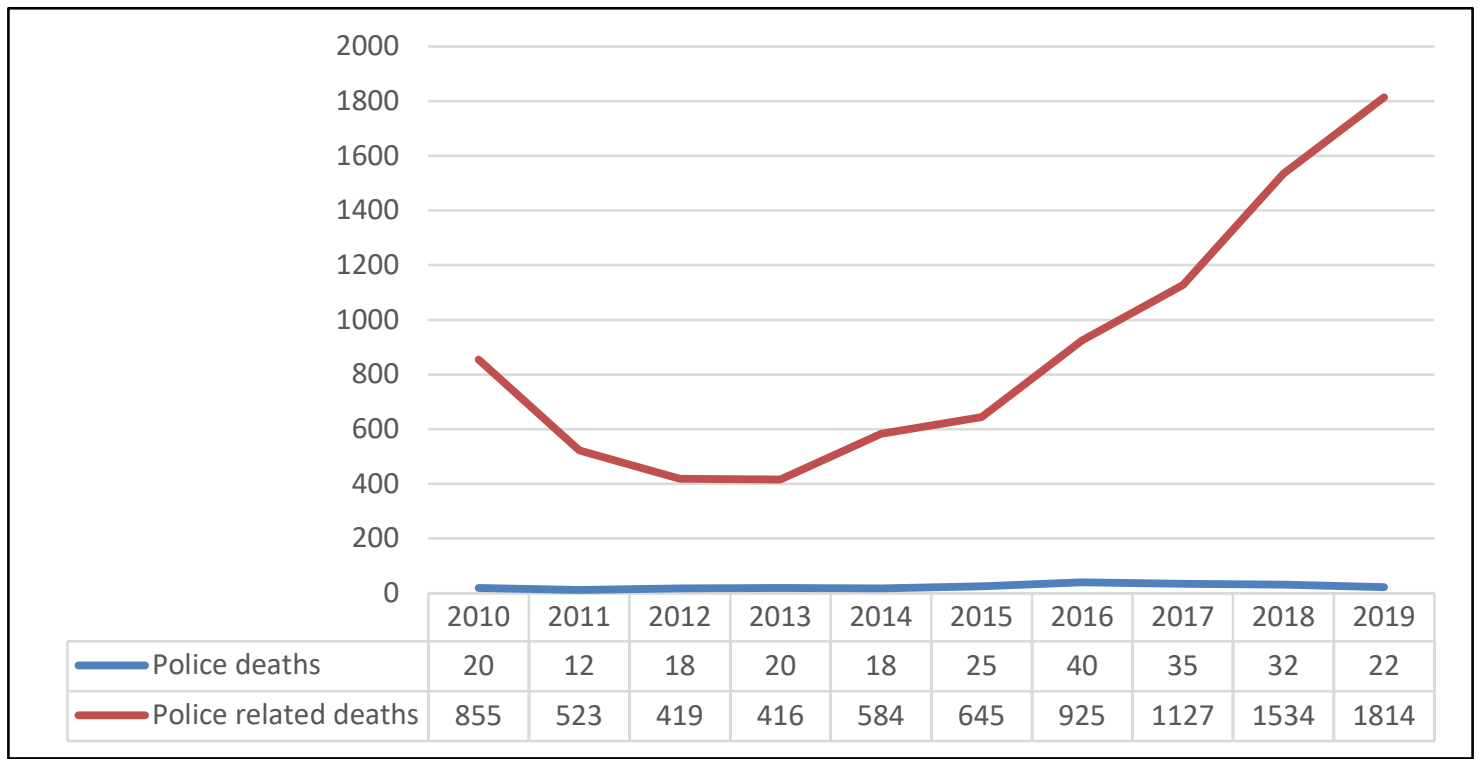

Graph 3. Comparative analysis of Police deaths and Police-related deaths.

(Source: Instituto de Segurança Pública do Rio de Janeiro -ISP - 2018.)

Since 2011, the Public Prosecutor's Office of the State of Rio de Janeiro has been identifying an approximation between the drug trafficking and militia groups in Rio de Janeiro. The criminal groups seek to maximize the gains obtained both in drug trafficking and in the "sale of security" for business and the population in general. According to an article in the newspaper O Globo (Werneck, Werneck and Souza 2019) based on reports from the MPRJ, this association would already have a significant dimension in the metropolitan region of Rio de Janeiro:

This agreement among criminal groups suggests the need to update the understanding of their roles in managing the criminal activities in Rio de Janeiro as well as in the organization of violence. This new scenario indicates the drop in the homicide rate may not necessarily be related to a public security policy, but to a new arrangement of the criminal groups or, as stated by Garzón-Vergara (2016), "regulation of violence" by nonstate violent actors.

An example supporting this explanation for the decrease in the homicide rate in Rio de Janeiro is the disarmament episode of the Bloque Cacique Nutibara $(\mathrm{BCN})^{11}$ in Colombia in 2003. The group kept its drug trafficking activity unchanged under the domain of Don

\footnotetext{
${ }^{11}$ Colombian paramilitary group connected to drug trafficking.
} 
Berna. ${ }^{12}$ During the period of a new configuration, the homicide rate in Medellín dropped from 184 homicides per 100,000 inhabitants in 2002 to somewhere around 30 homicides per 100,000 inhabitants between 2005 and 2007. However, with the deportation of Don Berna to the United States, in 2008, the homicide rate increased in the period 2008-2009 to 94.4 homicides per 100,000 inhabitants.

When analyzing the case of Rio de Janeiro based on what was observed in Colombia, it is possible to explore the idea that violence management may be regulating the activity of VNSAs. This scenario is beneficial to the State, which may exploit the positive data (drop-in homicide rate) and is also beneficial to criminal organizations that have a political dialogue with the State, offering parastatal management of urban violence.

When recognizing the existence and relevance of a rearrangement of roles among criminal groups in Rio de Janeiro, the state capacity as the central coordinator of the security policies is jeopardized. Therefore, the state of Rio de Janeiro builds walls from the inside out, and the emergence of new relationships among the several state and nonstate players around public security establishes a new dimension for the analysis of violence.

\section{Conclusion}

Since the last Brazilian presidential and gubernatorial election in 2018, it was possible to observe in the country and particularly in Rio de Janeiro, the adoption of public security policies linked to strategies of confrontation. In the period from 2018-2019, Rio de Janeiro showed that the number of homicides fell by around 21.5\%, according to Agência Brasil (Platonow 2019). ${ }^{13}$ Therefore, one could say that the policy of combating while increasing police killings is somehow effective as a strategy to provide public security.

However, the discussion carried out in this study demonstrates that - and it is subject to further debate - it is not possible to establish a comprehensive and linear correlation between the increase in police killing and reduction in the homicide rate. Therefore, a public security policy based exclusively on these grounds fails to recognize complex cause-effect relationships and the issues behind public policy efficiency.

Finally, we maintain that military interventions and militarization strategies, in this sense, operate to expand the margins between the legal and the illegal. Therefore, given the loss of meaning and trivialized violence, we follow Michel Foucault's recommendation and invert Clausewitz's proposition: politics is the extension of war, using other means. Power relations are finding their anchor in war and military mechanisms. Political power inserts these relationships in institutions, and guns turn into the true judges (Foucault 1999, pp. 22-23). In other words, since militarism, in addition to representing the model of a state of exception, a whole funeral ritual has opened up, which potentiates unpunished death. Also, it extrapolates, on a large scale, the whole punishment-centered perspective, which is an emblematic mark of genocidal politics.

\footnotetext{
12 Pseudonym adopted by the head of the group.

13 The data refer to the period between January and August 2019, compared to the same months in 2018 (Platonow 2019). Also, it is important to keep in mind that data on crime in Brazil are problematic because they are prepared without external oversight, i.e., the process lacks transparency.
} 


\section{References}

Agamben, G., 2004a. Estado de exceção. São Paulo: Boitempo.

Agamben, G., 2004b. Homo sacer: O poder soberano e a vida nua. Belo Horizonte: Editora da UFMG.

Agamben, G., 2017. O uso dos corpos. São Paulo: Boitempo.

Alves, J.C., 2003. Dos barões ao extermínio: Uma história da violência na Baixada Fluminense. Duque de Caxias: APPH Clio.

Amâncio, T., 2018. Mortes violentas avançam e batem novo recorde no país; polícia mata mais. Folha de São Paulo [online] 9 August. Available from:

https://www1.folha.uol.com.br/cotidiano/2018/08/mortes-violentas-avancam-ebatem-novo-recorde-no-pais.shtml [Accessed 9 July 2020].

Bauman, Z., 1999. Globalização: As consequências humanas. Rio de Janeiro: Jorge Zahar.

Bauman, Z., 2003. Comunidade: A busca por segurança no mundo atual. Rio de Janeiro: Jorge Zahar.

Beck, U., 2010. Sociedade de risco: Rumo a uma outra modernidade. São Paulo: Editora 34.

Benites, A., 2019. Plano Moro afrouxa regras para policiais que matam e sugere medidas que já foram barradas. El País [online], 5 February. Available from: https://brasil.elpais.com/brasil/2019/02/04/politica/1549311947 740805.html [Accessed 2 September 2019].

Betim, F., 2018. Menos latrocínios e mais mortes por policiais. Qual é o legado da intervenção no Rio? El País [online], 28 December. Available from: https://brasil.elpais.com/brasil/2018/12/27/politica/1545875863 659881.html?Fbcli d=IwAR0WpgN1lqQGLxNGSgnBB8H2ygYz2ht-1U3TDMbSPtOA9HOrPWDBnAIqgw [Accessed 30 January 2019].

Bianchi, P., 2017. Rio chama Exército contra violência pela $12^{\underline{a}}$ vez em 10 anos. Adianta? UOL [online], 29 July. Available from:

https://noticias.uol.com.br/cotidiano/ultimas-noticias/2017/07/29/rio-chamaexercito-contra-violencia-pela-12-em-10-anos-virou-rotina.htm?cmpid=copiaecola [Accessed 23 April 2018].

Burgos, M., 2002. A utopia da Comunidade: Rio das Pedras, uma favela carioca. Rio de Janeiro: Loyola.

Buzzan, B., Weaver, O., and Wilde, J., 1998. Security: A New Framework for Analysis. London: Liener.

Caldeira, T.P.R., 2001. Cidade de muros: Crime, segregação e cidadania em São Paulo. São Paulo: Edusp/Editora 34.

Call, C., 2003. Democratization, war, and state-building: Constructing the rule of law in El Salvador. Journal of Latin American Studies [online], 35(4), 827-862. Available from: https://doi.org/10.1017/S0022216X03007004 [Accessed 13 January 2021].

Chevigny, P., 2003. Edge of the Knife: Police Violence in the Americas. New York: The New Press. (Originally published in 1995). 
Clausewitz, C., 1996. Da guerra. São Paulo: Martins Fontes.

Constituição Federal, Lei Complementar nº 97/1999 [online]. 9 June. Available from: http://www.planalto.gov.br/ccivil 03/leis/lcp/lcp97compilado.htm [Accessed 13 January 2021].

Decreto nº 9.288 de 15 de fevereiro de 2018. Decreta intervenção federal no estado do Rio de Janeiro com o objetivo de pôr termo ao grave comprometimento da ordem pública. D.O.U. [online], Edição Extra. 16 February. Available from: http://legislacao.planalto.gov.br/legisla/legislacao.nsf/Viw Identificacao/DEC\%20 9.288-2018?OpenDocument [Accessed 13 January 2021].

Encarnación, O., 2016. The Trumpification of Latin American Right. Foreign Policy [online], 16 April. Available from: https:/foreignpolicy.com/2018/04/16/thetrumpification-of-the-latin-american-right/[Accessed 13 January 2021].

Fórum Brasileiro de Segurança Pública, 2018. Anuário Brasileiro de Segurança Pública 2018 [online]. São Paulo: FBSP. Available from: https://forumseguranca.org.br/wpcontent/uploads/2019/03/Anuario-Brasileiro-de-Seguranc\%CC\%A7aPu\%CC\%81blica-2018.pdf [Accessed 13 January 2021].

Fórum Brasileiro de Segurança Pública, 2019. Anuário Brasileiro de Segurança Pública 2019 [online]. São Paulo: FBSP. Available from: https://www.forumseguranca.org.br Lwp-content/uploads/2019/10/Anuario-2019-FINAL 21.10.19.pdf [Accessed 13 January 2021].

Foucault, M., 1999. Em defesa da sociedade. São Paulo: Martins Fontes.

Fox, S., and Hoelscher, K., 2012. Political order, development, and social violence. Journal of Peace Research [online], 49(3), 431-444. Available from: https://doi.org/10.1177/0022343311434327 [Accessed 13 January 2021].

Galtung, J., 1985. Twenty-five years of peace research: ten challenges and some responses. Journal of Peace Research [online], 22(2), 145-146. Available from: https://doi.org/10.1177/002234338502200205 [Accessed 13 January 2021].

Galtung, J., 1991. Peace by Peaceful Means: Peace and Conflict, Development and Civilization. Oslo: International Peace Research Institute (PRIO).

Garland, D., 2008. A cultura do controle: Crime e ordem social na sociedade contemporânea. Rio de Janeiro: Revan.

Garzón-Vergara, J.C., 2016. Qual é a relação entre o crime organizado e os homicídios na América Latina? Rio de Janeiro: Instituto Igarapé.

Godoy, A.S., 2006. Popular Injustice: Violence, Community, and Law in Latin America. Stanford University Press.

Godoy, R., 2013. Mais de 23 mil militares vão para as ruas na Copa das Confederações. O Estado de S. Paulo [online], 14 June. Available from:

https://esportes.estadao.com.br/noticias/geral,mais-de-23-mil-militares-vao-paraas-ruas-na-copa-das-confederacoes, 1042154 [Accessed 13 January 2021]. 
Goldstein, D., et al., 2007. La Mano Dura and the violence of Civil Society in Bolivia. Social Analysis [online], 51(2), 43-63. Available from: https://doi.org/10.3167/sa.2007.510203 [Accessed 13 January 2021].

Grundy, K., and Weinstein, M., 1974. The Ideologies of Violence. Columbus: Merrill.

Hagan, J., and Peterson, R., eds., 1995. Crime and Inequality. Stanford University Press.

Holland, A., 2013. Right on Crime? Conservative Party Politics and Mano Dura Policies in El Salvador. Latin American Research Review [online], 48(1), 44-67. Available from: https://doi.org/10.1353/lar.2013.0009 [Accessed 13 January 2021].

Instituto de Segurança Pública do Rio de Janeiro, 2018. [Rio de Janeiro Public Security Institute]. Letalidade violenta [online]. Data set. Available from:

http://www.ispvisualizacao.rj.gov.br/letalidade.html [Accessed 13 January 2021].

Jabri, V., 2007. War and the Transformation of Global Politics. London: Palgrave Macmillan.

Kleinfeld, R., and Barham, E., 2018. The complicit States and the governing Strategy of Privilege Violence: When Weakness Is Not the Problem. Annual Review of Political Science [online], vol. 21, 215-238. Available from: https://doi.org/10.1146/annurevpolisci-041916-015628 [Accessed 13 January 2021].

Koonings, K., and Kruijt, D., eds., 1999. Societies of Fear: The Legacy of Civil War, Violence and Terror in Latin America. London: Zed Books.

Kurtenbach, S., 2013. The "Happy Outcomes" May Not Come at All - Postwar Violence in Central America. Civil Wars [online], 15(sup. 1), 105-122. Available from: https://doi.org/10.1080/13698249.2013.850884 [Accessed 13 January 2021].

Lopes, A. Jr., 2017. Lei 13.491/2017 fez muito mais do que retirar os militares do tribunal do júri. Consultor Jurídico [online], 20 October. Available from: https://www.conjur.com.br/2017-out-20/limite-penal-lei-134912017-fez-retirarmilitares-tribunal-juri [Accessed 3 March 2018].

Manso, B.P., 2020. A república das milícias: Dos esquadrões da morte à era Bolsonaro. São Paulo: Todavia.

Misse, M., 2011. Crime Organizado e Crime Comum no Rio de Janeiro: Diferenças e Afinidades. Revista de Sociologia Política [online], 19(46-Dossiê Crime Segurança e Instituições Estatais: Problemas e Perspectivas). Available from: https://doi.org/10.1590/S0104-44782011000300003 [Accessed 13 January 2021].

Moser, C., 2004. Urban Violence and Insecurity: An introductory roadmap. Environment \& Urbanization [online], 16(2), 3-16. Available from: https://doi.org/10.1177/095624780401600220 [Accessed 13 January 2021].

Munck, G., 2003. Gobernabilidad democratic a comienzos del Siglo XXI: Una perspectiva Latinoamericana [Democratic governance at the beginning of the XXI century: A Latin American Perspective]. Revista Mexicana de Sociología [online], 65(3), 565-588. Available from: https://doi.org/10.2307/3541425 [Accessed 13 January 2021]. 
Neumayer, E., 2003. Good policy can lower violent crime: Evidence from a crossnational panel of homicide rates, 1980-1997. Journal of Peace Research [online], 40(6), 619-640. Available from: https://doi.org/10.1177/00223433030406001 [Accessed 13 January 2021].

Nieburg, H.L., 1968. Violence, Law, and the Social Process. American Behavioral Scientist [online], March (1). Available from: https://doi.org/10.1177/000276426801100406 [Accessed 13 January 2021].

Nóbrega, J.M.P. Jr., 2010. A militarização da segurança pública: um entrave para a democracia brasileira. Revista de Sociologia e Política [online], 18(35), 119-130. Available from: https://doi.org/10.1590/S0104-44782010000100008 [Accessed 13 January 2021].

O'Donnell, G., 1993. On the State, democratization and some conceptual problems: A Latin American view with glances at some post-Communist countries. World Development [online], 21(8), 1355-1369. Available from: https://doi.org/10.1016/0305-750X(93)90048-E [Accessed 13 January 2021].

Paoliello, T., and Miklos, M., 2017. Militarização da segurança pública no Rio e em todo o mundo. Open Democracy [online], 4 October. Available from:

https://www.opendemocracy.net/pt/militariza-o-da-seguran-p-blica-no-rio-e-emtodo-o-/ [Accessed 7 February 2019].

Pearce, J., 1998. From Civil War to Civil Society: Has the End of the Cold War brought Peace to Central America? International Affairs [online], 74(3). Available from: https://doi.org/10.1111/1468-2346.00036 [Accessed 13 January 2021].

Pereira, A., and Ungar, M., 2006. The Persistence of Mano Dura: Authoritarian Legacies and Policing in Brazil and Southern Cone. In: K. Hite and P. Cesarini, eds., Authoritarian Legacies in Southern Europe and Latin America. South Bend: University of Notre Dame Press.

Platonow, V. 2019. Rio: número de homicídios cai; mortes em confronto aumentam em 2019. Agência Brasil [online] 19 September. Available from:

https://agenciabrasil.ebc.com.br/geral/noticia/2019-09/rio-numero-de-homicidioscai-mortes-em-confronto-

aumentam\#: :text=A\%20taxa $\% 20 \mathrm{de} \% 20$ homic $\%$ C3\%ADdios $\% 20$ caiu, $2 \% 25 \% 2 \mathrm{C} \%$ 20no\%20mesmo\%20per\%C3\%ADodo [Accessed 13 January 2021].

Redação, 2018. A semana | Confira os principais fatos destacados pelo Brasil de Fato. Brasil de Fato, 23 February.

Rivera, M., 2016. The sources of social violence in Latin America: An empirical analysis of homicides rates, 1980-2010. Journal of Peace Research [online], 53(1), 84-89. Available from: https://doi.org/10.1177/0022343315598823 [Accessed 13 January 2021].

Rodgers, D., and Baird, A., 2016. Entender a las pandillas de América Latina: Una revisión de la literatura. Estudios Socio-Jurídicos [online], 18(1), 13-53. Available from: https://doi.org/10.12804/esj18.01.2016.01 [Accessed 13 January 2021].

Schmitt, C., 1992. O Conceito de Político. Trans.: A.L.M. Valis. Petrópolis: Vozes. 
Thyne, C., and Shroeder, R., 2012. Social constraints and civil war: Bridging the gap with criminological theory. Journal of Politics [online], 74(4), 1066-1078. Available from: https://doi.org/10.1017/S0022381612000655 [Accessed 13 January 2021].

United Nations Development Programme (UNDP), 2018. Human Development Indices and Indicators: 2018. Statistical update [online]. Available from:

http://hdr.undp.org/en/content/human-development-indices-indicators-2018statistical-update [Accessed 15 January 2021].

Velasquez, D.P., 2015. A (in)constitucionalidade da Força Nacional de Segurança Pública. Jus.com.br [online], March. Available from:

https:/jus.com.br/artigos/37331/a-in-constitucionalidade-da-forca-nacional-deseguranca-publica [Accessed 20 April 2018].

Vilela, P.R., 2018. Intervenção militar na segurança do Rio atinge os mais pobres e não resolve violência. Brasil de Fato [online], 23 February. Available from: https://www.brasildefato.com.br/2018/02/23/intervencao-militar-na-segurancado-rio-atinge-os-mais-pobres-e-nao-resolve-violencia/ [Accessed 23 April 2013].

Wacquant, L., 1999. Les prisons de la misère. Paris: Raisons d'Agir.

Werneck, A., 2019. Milícias chegam a 26 bairros do Rio e a outras 14 cidades do estado. O Globo, 31 March.

Werneck, A., and Souza, R.N.S., 2019. Narcomilícias: traficantes e milicianos se unem em 180 áreas do Rio, segundo investigação. O Globo, 10 October.

Wolin, S., 1960. Política y perspectiva: Continuidad y cambio en el pensamiento político occidental. Buenos Aires: Amorrortu.

Zaluar, A., and Conceição, I.S., 2007. Favelas sob o controle das Milícias no Rio de Janeiro que paz? São Paulo em Perspectiva [online], 21(2), 89-101. Available from: http://produtos.seade.gov.br/produtos/spp/v21n02/v21n02 08.pdf [Accessed 13 January 2021]. 